\title{
ROGERS V TELEVISION NEW ZEALAND LTD: POLICE AND THE RELEASE OF INFORMATION TO THE MEDIA
}

\author{
Laura Tidey*
}

\begin{abstract}
This article considers the flow of information from the police to the media in light of the Supreme Court case of Rogers v Television New Zealand Ltd (Rogers). While the police were not party to the action, and the conduct of the police was not relevant to the case argued, the Court was critical of the actions of the police. This article looks at the extent to which information gathered by the police and intended to be used as evidence is released by the police to the media; it finds that such information is frequently released. The article looks at the relevant law including Police Regulations, internal police rules and Code of Conduct, breach of confidence, contempt of court, and the Official Information Act 1982. The circumstances of the Rogers case are analysed in light of the relevant law and potential breaches are identified. The article concludes that the law relating to police release of information to the media needs to be clarified and that clearer, enforced police guidelines may achieve this.
\end{abstract}

\section{INTRODUCTION}

There is much contact between the police and the media in New Zealand. The flow of information from the police to the media is undoubtedly very important. The recent Supreme Court case of Rogers $v$ Television New Zealand Ltd (Rogers) ${ }^{1}$ involved a videotaped confession and reconstruction of an alleged murder given to the media by the police. While the police were not party to the action, and the conduct of the police was not relevant to the case argued, the Court was critical of the actions of the police. This suggests that there are issues relating to police release of information to the media.

This article will look at the extent information such as the Rogers tape, gathered by the police and intended to be used as evidence, is released by the police to the media and will find that such

* Submitted as part of the LLB(Hons) programme at Victoria University of Wellington. I would like to acknowledge the assistance of Steven Price.

1 Rogers $v$ Television New Zealand Ltd [2008] 2 NZLR 277 (NZSC) [Rogers]. 
information is frequently released. The article will look at the law relating to the release of such information including Police Regulations, internal police rules and Code of Conduct, breach of confidence, and contempt of court. It will address the impact of the Official Information Act 1982 (OIA). The circumstances of the Rogers case and the law or rules that may have been breached with the release of the video, justifying the criticism of the Supreme Court, will be discussed. The impact of the law and rules on the release of similar information will be considered. The article will suggest that the law needs to be clarified and that clearer and enforceble guidelines need to be available for police staff.

\section{ROGERS VTELEVISION NEW ZEALAND LTD: THE CASE}

The Supreme Court judgment of Rogers was released in November 2007. Noel Rogers was appealing a Court of Appeal decision allowing Television New Zealand (TVNZ) to broadcast footage of a confession and reconstruction of an alleged murder. In 1995 Rogers' uncle, Lawrence Lloyd, was convicted of the manslaughter of Katherine Sheffield. At the time of the initial investigation, and after Lloyd's conviction, Rogers made a series of confessions claiming responsibility for the death of Sheffield. Eventually the case was reopened. Lloyd's conviction was quashed in 2004 and Rogers was charged. ${ }^{2}$

While in police custody, Rogers was taken to participate in a videotaped reconstruction of Sheffield's death. ${ }^{3}$ During the reconstruction TVNZ was filming at a distance of around 50 metres. ${ }^{4}$ The police intended to use the tape at Rogers' trial ${ }^{5}$ and claim not to know how TVNZ knew about the reconstruction. ${ }^{6}$ Several weeks later an officer present at the reconstruction gave TVNZ a copy of the police tape. ${ }^{7}$ The Court of Appeal in Rogers' criminal trial found the video inadmissible as the circumstances of the filming denied his right to a lawyer under the New Zealand Bill of Rights Act. ${ }^{8}$

Some disagreement exists between the police and TVNZ over the use of the tape, in particular about the agreement as to when the tape could be broadcast. The police claim the agreement was that it could only be used once Rogers had been convicted, and when the tape had been ruled inadmissible the police officer who provided it advised TVNZ that they could not use it "in any 404-7125, para 5

5 Rogers, above n 1, para 76 McGrath J.

6 Affidavit of James Kenneth Taare, above n 4, para 5.

7 Ibid, para 10

$8 \quad R v$ Rogers [2006] 2 NZLR 156 (CA). 
material way". ${ }^{9}$ TVNZ claimed they were free to broadcast the tape if Rogers was acquitted, would wait until the conclusion of any appeal if Rogers was convicted, and would not broadcast the tape if there was a hung jury. ${ }^{10}$

Rogers was acquitted and subsequently discovered that TVNZ intended to broadcast the tape. ${ }^{11}$ He sought an injunction against TVNZ, his main argument being that broadcasting the reconstruction would breach his privacy. ${ }^{12}$ He succeeded in the High Court. ${ }^{13}$ TVNZ appealed and succeeded in the Court of Appeal. ${ }^{14}$ The Supreme Court affirmed this decision, finding that broadcasting the tape would not breach Rogers' right to privacy and that there was public interest in broadcasting it. ${ }^{15}$

\section{THE ISSUE OF POLICE RELEASE OF INFORMATION TO THE MEDIA}

\section{A Rogers v Television New Zealand Ltd}

The Supreme Court judgment in Rogers highlighted several unresolved elements in the case, including the release of the video by the police to TVNZ. Almost all the judges in the Supreme Court and previous hearings criticised the release of the tape by the police. Anderson J emphasised that: ${ }^{16}$

It cannot be assumed that what occurred in this case must necessarily have been irregular. Nor, given the absence of the police as a party and the paucity of the evidence would it be fair to suggest it was.

However, in the Supreme Court transcript, he was recorded as saying that "it seems very irregular that they should be dishing out copies of evidence to private recipients". ${ }^{17}$ Both Anderson $\mathrm{J}$ and Elias CJ were left feeling uneasy about the actions of the police. ${ }^{18}$ Blanchard $\mathrm{J}$ noted that the release of the tape to TVNZ was "[a] disturbing feature of the case". ${ }^{19}$ It is clear from the transcript

9 Affidavit of James Kenneth Taare, above n 4 , para 10-11.

10 Affidavit of Stephen Hunter Wells on behalf of Television New Zealand Ltd (14 December 2005) in the High Court of Auckland Registry, CIV-404-7125, para 6.

11 Rogers, above n 1, para 78 McGrath J.

12 Rogers, above n 1.

13 Rogers v Television New Zealand Ltd (2005) 22 CRNZ 668 (HC).

14 Rogers $v$ Television New Zealand Ltd [2007] 1 NZLR 156 (CA).

15 Rogers, above $\mathrm{n} 1$.

16 Ibid, para 142 Anderson J.

17 Supreme Court of New Zealand (14 December 2006) Transcript of Noel Clement Rogers and TVNZ, SC68/2006, para 22.

18 Rogers, above n 1, para 17 Elias CJ; para 142 Anderson J.

19 Ibid, para 46 Blanchard J. 
of the hearing that there was concern about this issue and disappointment that it was not originally pursued. ${ }^{20}$ William Young $\mathrm{P}$ in the Court of Appeal thought that the actions of the police "might be thought to be objectionable". ${ }^{21}$ In the High Court it was said that "there are good reasons why the police are not permitted to and do not usually behave in such a manner". ${ }^{22}$

Several issues were raised by the Supreme Court in relation to the release of the tape. It was suggested that there may have been a breach of the Police Regulations $1992 .{ }^{23}$ Elias CJ thought there may also have been a breach of confidence ${ }^{24}$ and McGrath J considered contempt of court or abuse of court process to be an issue. ${ }^{25}$

\section{B Police Disclosure to the Media in New Zealand}

There is much interaction between the police and the media. The police recorded 173 calls from one Auckland media outlet between the hours six am and ten pm over a period of seven days last year. ${ }^{26}$ Police rules encourage good relations with the media ${ }^{27}$ and "comment on issues the media [deems] to be of public interest". ${ }^{28}$

It is unlikely that the Rogers tape is an isolated example of such information being released by the police to the media. The Supreme Court seemed to think there was a wider issue. McGrath $\mathrm{J}$ is quoted in the court transcript as saying that "one senses that the police for various reasons do give out a lot of information to the media". ${ }^{29}$ The Independent Police Conduct Authority received 97 complaints of improper disclosure in a year from 2006 to $2007 .^{30}$

There have been other cases where evidence used in a trial has been given to the media by the police. In Jackson $v$ Canwest TVWorks Ltd a television company applied to the Court to copy a

20 See Supreme Court of New Zealand, above n 17, para 21 Elias CJ.

21 Television New Zealand v Rogers, above n 14, para 119 William Young P.

22 Rogers $v$ Television New Zealand Ltd, above n 13, para 48 Judgment of the Court.

23 Rogers, above n 1, para 15 Elias CJ; para 45 Blanchard J; para 110 McGrath J.

24 Ibid, para 15 Elias CJ.

25 Ibid, para 111 McGrath J.

Obtained under Official Information Act 1982 Request to the New Zealand Police 10 June 2008.

27 Police Media Services "M082 - Relationship with News Media Organisations" Ten-One 222/15 (Obtained under Official Information Act 1982 Request to the Police 10 June 2008).

28 Obtained under Official Information Act 1982 Request to the New Zealand Police 10 June 2008.

29 Supreme Court of New Zealand, above n 17, para 37, McGrath J.

30 Independent Police Conduct Authority Annual Report 2007 www.pca.govt.nz (accessed 9 August 2009), however it is unclear how many complaints relate to disclosure to the media. 
videotaped interview, but already had a copy from the police. ${ }^{31}$ Parts of police interviews are often seen on television. ${ }^{32}$ However, it can be difficult to determine for certain whether information that appears to have come from a police source actually did. Transcripts of 111 calls made by a woman before her disappearance in a highly publicised case found their way into the hands of a television journalist in 2004. ${ }^{33}$ While a Police Communications Centre staff member denied she had been the source, the leak was traced to her home. ${ }^{34}$ In another case, police investigated internally after a well known sportswoman called 111 to report a domestic incident and it was discovered a journalist had access to the job number assigned by the Police Communications Centre (suggesting a police leak). ${ }^{35}$

While the police claim the release of information like videotaped or recorded interviews is not routine, ${ }^{36}$ it is clear from these examples and the Rogers case that this must not be uncommon. Furthermore, it is likely such information is released more often than is obvious from news items, cases, and occasions where the police have investigated. A study by Cate Brett found that traditionally there were informal relationships "between individual police and trusted police reporters who were given access to 'backroom' knowledge on a non-disclosure basis". ${ }^{37}$

\section{THE LAW RELEVANT TO POLICE RELEASE OF INFORMATION TO THE MEDIA}

\section{A Police Regulations}

The Police Regulations 1992 were in force at the time the Rogers tape was released to the media. Regulation 7 deals with police disclosure of information. This states that "every member shall observe the strictest secrecy in relation to Police business and any information coming into the member's possession by virtue of his or her office". There are four exceptions: where authorised by the provisions of any Act; General Instructions; the authority of the Commissioner; and where

\footnotetext{
31 Jackson v Canwest TVWorks Ltd [2005] NZAR 499 (CA).

32 John Burrows "Media Law" (2002) NZ Law Rev 217, 237.

33 Obtained under Official Information Act 1982 Request to the New Zealand Police 24 July 2008.

34 Ibid.

35 Ibid.

36 Ibid.

37 Cate Brett Control of the Crime Story: Free Speech vs Fair Trial (University of Canterbury, Christchurch, 2001) 25.
} 
necessary, to do his or her duties. ${ }^{38}$ The Supreme Court thought there was a possible breach of regulation 7 in the Rogers case. ${ }^{39}$

Prima facie, this regulation would prevent the release of police information in all but the most limited circumstances. In Stepping Stones Nursery Ltd v Attorney-General (Stepping Stones), Harrison J commented that regulation 7 "reads as an absolute prohibition against releasing any such information unless for the purpose of satisfying one of the four specified exceptions". 40 Stepping Stones quotes a number of English cases to support this narrow interpretation of regulation $7 .{ }^{41}$ These cases reinforce the need to ensure "police do not abuse, in the sense of use for an unauthorised purpose, a statutory power which infringes those rights [of another individual]". ${ }^{42}$

As for the exceptions to "strictest secrecy", the Supreme Court seemed to have difficulty in finding any that might have applied in the Rogers case. ${ }^{43}$ However, the OIA, discussed below, may provide statutory authority. It would seem the Police Regulations 1992 were subject to the OIA as they came into force after 1983, the date specified the savings provision of the Act. ${ }^{44}$ Blanchard J thought the police may have acted beyond their powers in handing over the tape as this "does not appear to have been taken with a view to investigating the death of Ms Sheffield or prosecuting the case against Mr Rogers". ${ }^{45}$ The High Court noted that "[it] is difficult to conceive of any proper purpose being served by such an action". 46 The General Instructions, discussed below, do not seem to provide any authority for the release of a videotape in the circumstances of Rogers.

Without further information it is difficult to determine if regulation 7 was breached in Rogers, and the Court made no such findings. However, it seems likely that it was. It is clear from the wording of regulation 7 and the comments in Rogers and Stepping Stones, that there is an obligation of secrecy and the exceptions are limited.

However, the Police Regulations 1992 were repealed by section 130(5) of the Policing Act 2008. While a Cabinet Minute from 2007 suggests that the original intention was to retain and

38 Police Regulations 1992, reg 7.

39 Rogers, above n 1, para 15 Elias CJ; para 45 Blanchard J; para 110 McGrath J.

40 Stepping Stones Nursery Ltd v Attorney-General [2002] 3 NZLR 414, para 33 (HC) Harrison J [Stepping Stones].

41 Ibid, para 34-37 Harrison J.

42 Ibid, para 42 Harrison J.

43 See Rogers, above n 1, para 110 McGrath J.

44 Official Information Act 1982, s 52(3)(b).

45 Rogers, above n 1, para 45 Blanchard J.

46 Rogers $v$ Television New Zealand Ltd, above n 13, para 52 judgment for the Court. 
transit regulation 7 into a new Act or regulations with minor language updating, ${ }^{47}$ there is currently no equivalent provision in the Policing Act 2008 or regulations. There is provision under the Act for the creation of regulations (although not specifically in relation to police information) ${ }^{48}$ so regulation 7 may be replaced in time. The police Code of Conduct (discussed below) deals with the requirement of confidentiality and has similarities to regulation 7 .

\section{B Internal Police Rules}

A number of General Instructions have been issued to police staff, some relevant to the release of information such as the Rogers tape. Requests for input into a current affairs programme or documentary should be discussed with the District Communications Manager and the General Manager: Public Affairs. ${ }^{49}$ These guidelines state that a: ${ }^{50}$

formal signed contract that has been approved by the Legal Section is required for all current affairs programmes or feature articles for which access to Police files, or live filming of police at work is required.

The arrangements in Rogers were informal to the point of disagreement between the police and TVNZ about when TVNZ could broadcast the video. There was no mention in the case of a formal signed contract approved by the legal advisors, which could be expected to resolve such disagreement. While TVNZ said the police officer had indicated that he had consulted his superiors, it is not clear that the release was discussed with appropriate people. ${ }^{51}$ Rather than authorising police to release information such as the Rogers tape to the media, the General Instructions seem to suggest caution. For example, an offender's photograph should not be released except when in the public interest and after discussion with legal advisors. ${ }^{52}$

47 Cabinet Minute "Police Act Review: Administrative and Miscellaneous Matters" (19 September 2007) CM22/8.

48 Policing Act 2008, s 102.

49 Police Media Services "M085- Guidelines for Communicating with Current Affairs Features (including Films, Documentaries, Fly-on-the-Wall, Reality TV Programmes and in-depth Print Media Articles)" TenOne 222/15 (Obtained under Official Information Act 1982 Request to the New Zealand Police 10 June 2008).

50 Ibid.

51 Affidavit of Stephen Hunter Wells on behalf of Television New Zealand, above n 10, para 6.

52 Police Media Services "M086- Media Access to Police Files, Documents, Videos, Photographs and Archival Material" Ten-One 222/15 (Obtained under Official Information Act 1982 Request to the New Zealand Police 10 June 2008). 
The instructions point to other areas of the law applying to police information, without providing much further guidance. They refer briefly to regulation 7 (now repealed). ${ }^{53}$ Media requests for "access to police files, documents, videos, photographs, tape recordings and archival material" are said to fall under the OIA and the Privacy Act 1993. ${ }^{54}$ However, unless a member of the media is requesting information about themselves, the request is covered by the OIA, to which the Privacy Act is subject. ${ }^{55}$ The instructions note that the Criminal Proceedings (Search of Court Records) Rules 1974 apply to requests for information produced as an exhibit during criminal proceedings. ${ }^{56}$ The law of contempt of court is referred to and the instructions suggest avoiding comments that may lead to trial by media, or prejudice the fairness of any trial, or prejudice a prosecution. ${ }^{57}$

Other police documents provide clearer guidance with regards to Rogers. Police College training notes state that while the court may sometimes release interview tapes used in court "the tapes may not be released by the police". ${ }^{58}$ In a brief discussion of sub judice contempt, the information which ought not to be released includes "any confession". 59 A police media relations document reiterates this. ${ }^{60}$ In the case of homicide enquiries, police media documents advise that any information released before the trial begins ought to be non-contentious. ${ }^{61}$ It is clear that the police in releasing the Rogers tape were not following their own policy.

Subsequent to the release of the Rogers tape, the police have developed a Code of Conduct. The parts of the Code that deal with confidentiality are relevant to the release of such information by the police. Police employees should "observe and protect the rights of others to privacy and confidentiality". ${ }^{62}$ Possible breaches of confidence and privacy in relation to the release of such

53 Police Media Services "M083- Guidelines for Communicating with News Media" Ten-One 22/15 (Obtained under Official Information Act 1982 Request to the New Zealand Police 10 June 2008).

54 Police Media Services, above n 52.

55 Privacy Act 1993, s 7(1).

56 Police Media Services, above n 52.

57 Police Media Services "M089-Subjudice Rules in Criminal Cases" Ten-One 222/15 (Obtained under Official Information Act 1982, Request to the New Zealand Police 10 June 2008).

58 Criminal Investigation Branch, Training Service Centre at the Royal New Zealand Police College "Media" Selection and Induction Course (last updated August 2003) 6 (Obtained under Official Information Act 1982, Request to the New Zealand Police 24 July 2008).

59 Ibid, 7.

60 New Zealand Police Media Relations (April 2003) 1 (Obtained under Official Information Act 1982, Request to the New Zealand Police 24 July 2008).

61 New Zealand Police Homicide: Media Strategy (27 February 2008) 11 (Obtained under Official Information Act 1982, Request to the New Zealand Police 24 July 2008).

62 New Zealand Police Code of Conduct www.police.govt.nz (accessed 7 February 2009). 
information are discussed below. The Code contains the general statement that "[information] that comes into an employee's possession in the course of their duties must be treated in confidence and used only for official purposes". 63 Such information must only be used "in accordance with applicable standards, policies and directives" and that "confidential, personal or sensitive information" ought not to be divulged "outside of official duties or as otherwise required by the law". 64

The wording of the section relating to confidentiality reflects, and appears to substantially replace, regulation 7 (discussed above). The Code places particular importance on confidentiality of police information classing "allowing unauthorised access to, or disclosure of any matter or information in relation to Police business" as serious misconduct. ${ }^{65}$

\section{Breach of Confidence}

\section{Breach of confidence and the Rogers tape}

Elias CJ, in the Supreme Court decision of Rogers, thought that potential breach of confidence by the police was an unresolved issue, as was any possible resulting obligation of confidence owed to Rogers by TVNZ ${ }^{66}$ and the case should be sent back to be reconsidered. ${ }^{67}$ The majority decided the case on the pleaded claim of breach of privacy.

Breach of confidence and privacy, while related, pose different questions. Breach of confidence is based on the circumstances in which the information is communicated and looks at the conscience of the person receiving the confidence, while privacy is based on the information itself and focuses on the subject of the information. ${ }^{68}$ The tort of privacy requires the information to be publicised ${ }^{69}$ so any action over released information is likely to be against the media rather than the police, although privacy issues may possibly arise in a situation where the police release information in a press statement or during a press conference. Although Rogers was unsuccessful in establishing breach of privacy, this does not preclude a possible breach of confidence. Depending on the circumstances, there may well be a breach of confidence in other situations where information such as the Rogers tape is released to the media by the police.

63 Ibid.

64 Ibid.

65 Ibid.

66 Rogers, above n 1, para 2 Elias CJ.

67 Ibid para 8 Elias CJ.

68 John Burrows and Ursula Cheer Media Law in New Zealand (5ed, Oxford, South Melbourne, 2005) 230.

69 Hosking v Runting [2004] 1 NZLR 1, para 117 (CA) Gault P and Blanchard J. 
The elements of breach of confidence are that the information must be of a confidential nature, communicated in circumstances importing an obligation of confidence, and there must be an unauthorised use possibly to the detriment of the person communicating the information. ${ }^{70}$ As this is an equitable doctrine, the courts have discretion in providing a remedy. These elements will be considered below, in light of the Rogers case, focusing on any obligation of confidence owed by the police.

\section{Confidential information}

It is likely the Rogers tape would be confidential information, at least at the time the police released the information. In the English case of Hellewell $v$ Chief Constable of Derbyshire (Hellewell) a mug shot was deemed to be confidential information as it would "at least convey the information that the plaintiff was known to the police". ${ }^{71}$ The Rogers tape would certainly do the same. The information must not be common knowledge. ${ }^{72}$ While Rogers had made several confessions and it is possible this was widely known when the tape was given to TVNZ, a video provides another level of detail. ${ }^{73}$ It is likely that many of the details contained in the video would not be widely known.

\section{Circumstances importing an obligation of confidence}

The information must be disclosed in circumstances importing an obligation of confidence. This obligation may be based on the relationship between the parties. ${ }^{74}$ A relationship between the police and an individual could fall into such a category. Police have a general obligation to keep information confidential. ${ }^{75}$ This obligation arises out of police powers and the need to ensure they are not abused. ${ }^{76}$ This obligation is reflected in the police Code of Conduct (discussed above). The police cannot simply deal with information gathered as part of their duties as they see fit. ${ }^{77}$

Of course, someone in Rogers' situation cannot expect absolute confidentiality as "[the] very purpose of the police, which must be well understood by the person who makes the statement, is to obtain material from the statement with a view to putting it in evidence before a court". ${ }^{78}$ However,

70 Coco v AN Clark (Engineers) Ltd [1969] RPC 41, 47-48 (HC) Megarry J.

71 Hellewell v Chief Constable of Derbyshire [1995] 4 All ER 473, 475 (QB) Laws J [Hellewell].

72 Coco v AN Clark (Engineers) Ltd, above n 70, 47-48 Megarry J.

73 Rogers, above n 1, para 100 McGrath J.

74 Hellewell, above n 71, 476 Laws J.

75 Stepping Stones, above n 40, para 28 Harrison J.

$76 \quad R v$ Chief Constable of North Wales Police [1997] 4 All ER 691 (QB).

77 Rogers, above n 1, para 17 Elias CJ.

78 Ibid, para 48 Blanchard J. 
this "does not mean that [the person] can have no expectation of privacy in relation to a different use in other circumstances". ${ }^{79}$ The Office of the Ombudsmen has expressed a similar view, saying it is reasonable for a person in such a situation to "expect that such records would not be made available to the public - save as might be appropriate for the purpose of any court proceedings" ${ }^{80}$ It seems the same argument would apply to breach of confidence.

An obligation of confidence does not apply when information is released for a legitimate police activity. In Hellewell the Court found that the police could make reasonable use of information gathered while a duty of confidence remains in other circumstances. ${ }^{81}$ Legitimate police activity was discussed in Brown $v$ Attorney-General where although the police took a photograph of the plaintiff with his consent, the Court found it "was taken in circumstances that established a degree of confidence that the photograph would only be used for legitimate police purposes". ${ }^{82}$ The photograph was used in a pamphlet produced by the police, disclosing that the plaintiff was a convicted paedophile. The Court considered that express consent was required to use the photograph in this way. Breaches of police criminal profiling guidelines were considered relevant. ${ }^{83}$ Similarly, the possible breaches of the police rules may be relevant to any breach of confidence in Rogers.

It is arguable that the circumstances imported an obligation of confidence in Rogers. Someone in Rogers' situation may reasonably expect the tape would only be used for legitimate police purposes, such as presenting evidence at a trial, and that an obligation of confidence would apply in all other situations. However, perhaps Rogers ought to have known his situation was different. TVNZ reporters and crew present at the reconstruction were at a distance of about 50 metres. ${ }^{84}$ Rogers had already confessed on several occasions. It may be reasonable to expect that he would not have considered the reconstruction entirely confidential and that he would have realised at least some footage would be broadcast.

\section{Unauthorised use and detriment}

The need for the unauthorised use of the information to be to the detriment of the confider is a disputed element of breach of confidence. ${ }^{85}$ However, there would likely be some detriment to Rogers in the release of the information to TVNZ as this was likely to be, and was broadcast to a

79 Ibid, para 145 Anderson J.

80 Office of the Ombudsmen "Privacy-Videotaped Interviews" (1997) 3/1 Ombudsmen Quarterly Review 4.

81 Hellewell, above n 71, 475 Laws J.

82 Brown v Attorney-General [2006] DCR 630, para 97 (DC) Judge RLB Spear. Ibid, para 75 Judge RLB Spear.

84 Affidavit of James Kenneth Taare, above n 4, para 5.

85 Coco v AN Clark (Engineers) Ltd, above n 70, 48 Megarry J. 
large audience after the Supreme Court decision. Rogers was concerned about publicity "pointing to anger and threats directed to him in the Northland community from which he comes". 86

\section{Public interest}

There is a public interest defence to breach of confidence by the police if information is disclosed in line with police duties. ${ }^{87}$ This is also relevant to whether the circumstances import an obligation of confidence. Police duties include "detection of crime, the investigation of alleged offences and the apprehension of suspects or persons unlawfully at large" and in such situations "common sense and law alike dictate" that there should be no sanctions against the police. ${ }^{88}$ Stepping Stones considered such exceptions were only available in "extreme circumstances" where disclosure is necessary to protect the public and "even then the disclosure must be limited to one who has a proper interest in receiving the information". ${ }^{89}$ English cases also support a public interest defence to disclosure by the police that is limited to legitimate police duties. ${ }^{90}$

There will always be public interest in a murder case and especially one such as Rogers where another has already served time. However, it seems confidentiality would outweigh public interest in the police releasing the Rogers tape to TVNZ at the time they did. The public interest defence is strictly applied in cases concerning the police in order to meet wider public interest concerns. ${ }^{91}$ There appears no link between releasing the tape, especially pre-trial, and any legitimate police activity. The breaches of the police rules, as discussed above, show this is not accepted police activity. Any public interest in releasing the tape would, at that time, have been served by producing the tape as evidence in court. The media could access information about the case from the court. The Supreme Court indicated this tape would have been released on application by the media post trial when other public interest issues relating to the decision to exclude it had arisen. ${ }^{92}$

86 Rogers, above n 1, para 3 Elias CJ.

87 Stepping Stones, above n 40, para 33 Harrison J.

Hellewell, above n 71, 479 Laws J.

89 Stepping Stones, above n 40, para 45 Harrison J.

$90 R v$ Chief Constable of the North Wales Police ex parte AB, above n 76, 699 Lord Bingham CJ; Hellewell, above n 71, 479 Laws J.

91 Stepping Stones, above n 40, para 45 Harrison J; Hellewell, above n 71, 479 Laws J; $R v$ Chief Constable of the North Wales Police expart AB, above n 78, 699 Lord Bingham CJ.

92 Rogers, above n 1, para 46 Blanchard J. 


\section{Contempt of Court}

\section{Sub judice}

Police, when releasing information to the media before a trial, may sometimes be in contempt of court. The relevant legal issue is the sub judice rule. Solicitor-General $v$ Wellington Newspapers Ltd summarises what is required for contempt of court: ${ }^{93}$

To establish contempt he has to show that as a matter of practical reality the actions of the particular respondent caused a real risk, as distinct from a remote possibility, of interference with the administration of justice; here, specifically, interference with a fair trial.

The Court must consider if there are public policy considerations to mitigate contempt, ${ }^{94}$ however this defence has not had much success in case law. ${ }^{95}$ It is clear, as the High Court said in Rogers, that "early release of evidential videotapes in particular has the potential to impact seriously on an accused's fair trial rights". ${ }^{96}$ Evidence that contains a confession or suggests guilt would seem to be prejudicial, as would any evidence that could be seen by the jury outside of the control of court procedures. If the video had been broadcast by TVNZ before the trial, a fair trial would surely be compromised. A definition of contempt of court adopted by the New Zealand Law Commission includes "any acts done, outside court which are intended or likely to interfere with or obstruct the fair administration of justice". ${ }^{97}$ The act of releasing potentially prejudicial pre-trial information to the media knowing it may be published would seem to fall within this definition.

In an Australian case a police officer was found in contempt when the officer made a pre-trial statement suggesting that a person charged with a crime was guilty. ${ }^{98}$ However, often the proceedings are only against the media. An Australian case with facts close to Rogers is AttorneyGeneral for NSW v TCN Channel Nine Pty Ltd where the media, but not the police, were found in contempt. ${ }^{99} R v$ Coghill ${ }^{100}$ is another case where the media gained information from the police but the police were not a party to proceedings. The police gave the media the names of people under investigation. While the police requested they not be published, they were. This was not a contempt of court case, although Cooke P recognised that it easily could have been and issued a warning to

93 Solicitor-General v Wellington Newspapers Ltd [1995] 1 NZLR 45, 47 (CA) Eichelbaum CJ.

94 Ibid.

95 J F Burrows "Media Law" (1996) 3 NZ Law Rev 342, 355.

96 Rogers $v$ Television New Zealand Ltd, above n 13, para 52 Judgement of the Court.

97 New Zealand Law Commission Juries in Criminal Trials (NZLC R69, Wellington, 2001) para 459.

99 Attorney-General for NSWv TCN Channel Nine Pty Ltd (1990) 20 NSWLR 368 (CA).

$100 R v$ Coghill [1995] 3 NZLR 651 (CA). 
the police about releasing information "which may be published to the prejudice of persons who are or may be in future charged in criminal proceedings". ${ }^{101}$ His Honour clearly considered that the police have a duty to ensure that their actions do not affect a fair trial. It seems clear that the police, in supplying such information, are at risk of being in contempt of court.

In Rogers the tape was not broadcast until after the criminal trial so prejudice to a fair trial does not seem an issue. The release of prejudicial information is only contempt of court before or during a trial and afterwards constraints are removed. ${ }^{102}$ However, an agreement to withhold from publishing the information until after the trial is no guarantee there will be no contempt of court. A crime reporter and former police media liaison officer advises police against speaking off the record "no matter how much you trusted them because at the end of the day they will find a way to use that information". ${ }^{103} R \vee$ Coghill illustrates how agreements made with the media cannot always be relied on. ${ }^{104}$ A video re-construction or interview, or other evidence such as an affidavit, could be described or referred to without being broadcast or published. The police should not release information where there is such a risk, and such a risk cannot be fully eliminated, especially with an informal, disputed agreement such as in the Rogers case. The police recognise "[it] is virtually impossible to guarantee compliance from the media with any conditions which are laid down"105 and advise trainees not to give information "off the record" as "it is dangerous in that you risk your comments being reported by unscrupulous journalists". ${ }^{106}$ Further, the law of contempt "also exists to protect the public interest in the integrity of the justice system generally"107 whether or not fair trial rights are actually affected.

\section{Abuse of court process}

Blanchard, Tipping and McGrath JJ decided Rogers on the hypothetical basis that TVNZ was applying to the Court for access to the tape. However, TVNZ received the tape directly from the police. McGrath $\mathrm{J}$ suggested that the police, in removing the videotape from the control of the Criminal Proceedings (Search of Court Records) Rules 1974, had abused court process. ${ }^{108}$ The

101 Ibid, 672 Cooke P.

102 Attorney-General v TV3 Network Services Ltd (8 March 1996) HC INV CP 2/96.

103 Cate Brett, above n 37, 31.

$104 R v$ Coghill, above n 100.

105 New Zealand Police, above n 61, 12.

106 Criminal Investigation Branch, above n 58, 11.

107 Solicitor-General v Fairfax New Zealand Limited (10 October 2008) HC WN CIV-2008-485-705, para 75 (HC) Randerson and Gendall JJ.

108 Rogers, above n 1, para 110 McGrath J. 
Court would normally control access once evidence is submitted. ${ }^{109}$ Where access has otherwise been obtained "[it] may be that in these circumstances the Court has inherent powers to supervise and protect its records". ${ }^{110}$ His Honour said that this is based on the well established inherent powers of the High Court to prevent abuse of process. ${ }^{111}$ Court control is important as "[the] Court's capacity to give due protection from misuse of such material ... is necessary to maintain public confidence in the integrity of criminal trials". ${ }^{112}$ This would impact on the law regarding police release of information to the media in all situations where that material is or will be part of a court file. The courts often consider it necessary to deny access to information similar to the Rogers tape $^{113}$ and balance various interests when making such decisions. ${ }^{114}$ This ability would arguably be redundant if access could be sought from elsewhere.

Elias CJ criticised the hypothetical Search Rules application approach, saying it left many issues in Rogers unresolved. ${ }^{115}$ Her Honour cast doubt on McGrath J's abuse of court process argument, saying the hypothetical approach "assumes court control of a copy on no very sound foundation". ${ }^{116}$ Elias CJ referred to comments from the Supreme Court of Canada that on one view the property of an exhibit remains with the party producing it. ${ }^{117}$ Hunt $v$ A dealt with the publishing of information contained in court files but obtained from one of the parties, and alleged contempt of court. ${ }^{118}$ Hammond J said the Search Rules "do not, on their terms, apply to any person who has no need - because they are already in possession of the relevant information - to apply to the court". ${ }^{119}$ The Court considered any argument that "what is going on during a court hearing is somehow entirely the property of the court and under the control of the judge" was misconceived. ${ }^{120}$ These authorities present a strong case against McGrath J's dicta that the police would be abusing the court process by removing exhibits from the control of judges.

\author{
109 Ibid, para 108 McGrath J. \\ 110 Ibid, para 109 McGrath J. \\ 111 Ibid, para 111 McGrath J. \\ 112 Ibid, para 112 McGrath J. \\ $113 R v$ Mahanga [2001] NZLR 641 (CA). \\ 114 John Burrows "Media Law" (2006) 4 NZ Law Rev 769, 783. \\ 115 Rogers, above n 1, para 8 Elias CJ. \\ 116 Ibid. \\ 117 Vickery v Nova Scotia Supreme Court (Prothonotary) [1991] 1 SCR 671, 682 (SCC) Stevenson J. \\ 118 Hunt $v$ A [2008] 1 NZLR 368 (CA). \\ 119 Ibid, para 53 Hammond J. \\ 120 Ibid, para 51 Hammond J.
}




\section{E The Official Information Act}

\section{Release of information under the Act}

Any request made by the media to the police for information such as the Rogers tape is covered by the OIA. While this Act was not mentioned in Rogers, it seems from the affidavit of the police officer that TVNZ requested the tape. ${ }^{121}$ Under the police rules and Code of Conduct, confidentiality is excepted where required by law. The police must release the information if required by the Act.

Section 5 of the Act states "that the information shall be made available unless there is good reason for withholding it". A conclusive reason under section 6 for withholding information (not requiring consideration of public interest) is if the release would be likely to "prejudice the maintenance of the law including the prevention, investigation and detection of offences, and the right to a fair trial". ${ }^{122}$ There must be a "serious or real and substantial risk to a protected interest, a risk that may well eventuate". ${ }^{123}$ If people supplying information to the police know it could end up in media hands they may be less likely to participate. As discussed above there is a risk that releasing such information before or during the trial may compromise a fair trial. It is at least arguable that releasing such information to the media may prejudice the maintenance of law and fall under this exception to the Act.

Section 9 of the Act permits information to be withheld on certain grounds if not outweighed by public interest. One is "privacy of a natural person". ${ }^{124}$ While in Rogers the Supreme Court found no breach of privacy, it is not difficult to envisage a situation where the release of similar information may breach someone's privacy. The Office of the Ombudsmen allowed the police to withhold a videotaped interview of someone who had been charged, pleaded guilty and sentenced, pursuant to this ground. ${ }^{125}$ Another ground relates to protecting information subject to an obligation of confidence. ${ }^{126}$ This applies where releasing such information "would likely prejudice the supply of similar information, or information from the same source" and there is public interest in the information continuing to be supplied, or if the release "would be likely to otherwise damage public interest". ${ }^{127}$ Whether or not there was an obligation of confidence in Rogers, discussed above, it is

121 Affidavit of James Kenneth Taare, above n 4, para10-11.

122 Official Information Act 1982, s 6(1)(c).

123 Commissioner of the Police v Ombudsmen [1988] 1 NZLR 385, quoted in Office of the Ombudsmen (2001) "Conclusive withholding provisions" 12 Case Notes, 74-77.

124 Official Information Act 1982, s 9(2)(a).

125 Office of the Ombudsmen, above n 80.

126 Official Information Act 1982, s 9(2)(ba).

127 Ibid. 
possible similar information would be subject to an obligation of confidence. If people are aware that such information may be released to the media they will be less likely to provide it.

Section 9 requires consideration of public interest factors. The public interest factors relating to Rogers' privacy claim would not have applied when the tape was initially handed over by the police. Rogers had not yet been acquitted amid controversy after the tape had been ruled inadmissible. The police did not appear to consider the tape would be ruled inadmissible and could not have foreseen any public interest in debate about inadmissible evidence. It is possible that other public interest factors may have been considered by the police, however it is unknown if any were. Any balancing undertaken by the police was not outlined in court documents. In addition to sections 6 and 9, sections 18(c)(ii) and 52(1) make it clear that requests can and ought to be refused if making the information available would result in contempt of court. This test "is demanding and requires something close to certainty"128 and probably would not be met in the circumstances of Rogers.

The Rogers tape probably should not have been released by the police under the OIA when requested by TVNZ. It is likely that one of the grounds to withhold would have applied. It is unclear if the Act was considered at all. The general approach of the police to release of information relating to a criminal trial under an OIA request is to withhold it to protect any future evidence except on a successful appeal by the media to the ombudsmen. ${ }^{129}$ The release of the Rogers tape clearly goes against this approach. It is unclear if the officers involved had authority to release official information. However, meeting one of the withholding provisions seems not to impose an obligation to withhold under the OIA. ${ }^{130}$

\section{Proceedings relating to information made available}

Even if there are reasons for withholding information under the Act, section 48 may apply. This section bars proceedings relating to the release of information under the Act "[where] any official information is made available in good faith pursuant to this Act". ${ }^{131}$ This may protect the police from any action relating to breach of confidence and contempt of court. In Stepping Stones it is acknowledged that the English police breach of confidence cases would likely have been decided differently if such legislation applied. ${ }^{132}$ However, where the police release information without a request they will not have the protection of section $48 .^{133}$

128 Ian Eagles et al Freedom of Information in New Zealand (Oxford University Press, Auckland, 1992) 456.

129 Obtained under Official Information Act 1982, Request to the New Zealand Police 24 July 2008.

130 Ian Eagles et al, above n 128, 137.

131 Official Information Act 1982, s 48(1).

132 Stepping Stones, above n 40, para 42 Harrison J.

133 Ibid. 
It has been suggested that the police must be consciously dealing with the release as an OIA request for section 48 to apply. In Director of Human Rights Proceedings v Commissioner of Police a man asked the police for information about domestic violence complaints made by his ex-partner and two children against her current partner. The ex-partner complained that releasing this information breached her privacy. The police officer could not remember if he dealt for the request under the Act and the tribunal said he could only rely on section 48 if it was established on the balance of probabilities that he did. ${ }^{134}$ Practically, without an admission by the police, this would be difficult to prove. Once this is established, the tribunal said "[i]t is not really for us to say whether in doing so they applied the relevant elements of the OIA correctly..."135 If the request by TVNZ was dealt with under the Act, it would not matter if the information ought not to have been released under the terms of the Act. This is because "pursuant to the Act" applies even where there are grounds to refuse. ${ }^{136}$

The information must be made available in good faith for section 48 to apply. The definition of "good faith" in section 48 was considered by the High Court in $X v$ Attorney-General. ${ }^{137}$ The definition of "honestly and with no ulterior motive" was adopted. ${ }^{138}$ It is difficult to analyse whether the Rogers tape was released in good faith on the information available but factors that may be important are the unofficial way the tape was released, and the breaches of the police internal rules discussed above.

Section 48 would bar any proceedings relating to release of information such as the Rogers tape to the media, assuming that the information was requested and not supplied on police initiative, the request was processed under the OIA, and the information was supplied in good faith. Whether this occurred in Rogers is unclear. Under section 48(2), this protection would not extend to any proceedings against the media for breach of confidence.

\section{CLARIFICATION AND ENFORCEMENT OF THE LAW RELATING TO POLICE RELEASE OF INFORMATION TO THE MEDIA}

\section{A The Impact of Unclear Law and Rules and Lack of Compliance}

The law and rules relating to police release of information to the media are fragmented and unclear, resulting in information being released by the police when it should be withheld and

134 Director of Human Rights Proceedings v Commissioner of Police (13 November 2007) Human Rights Review Tribunal, 23/2007, HRRT 45/07, para 21.

135 Ibid, para 22.

136 Attorney-General v Davidson [1994] 3 NZLR 143 (CA) Cooke P.

137 X v Attorney-General [1994] NZFLR 433 (FC), following Central Estates (Belgravia) Ltd v Woogar [1971] 3 All ER 647 (CA).

138 Ibid. 
withheld when it should be released. However, sometimes the issue is compliance and enforcement. The potential impacts are discussed below.

Police release of information may impact on various rights of an individual. Information such as the Rogers tape may be subject to an obligation of confidence owed by the police. There are obvious consequences when this obligation is breached. There "may be further public interest in the reintegration into the community of those who have been interviewed by the police"139 and this would be difficult if interviews were routinely released to the media. While Roger's privacy claim was dismissed, in some situations police release of information could raise privacy issues. In addition, while there may not have been any prejudice to Rogers' trial, there is potential for this to occur in similar cases. While research suggests that publicity before and during a trial has "little if any effect on jurors", ${ }^{140}$ the effect on jurors would likely increase if publicity increased. ${ }^{141}$ As long as the law relating to the release of information by the police to the media is unclear and is being breached, there will be impacts on individual rights.

There may also be impacts on future supply of information to the police. Some suspects may be discouraged from participating in video interviews or reconstructions. ${ }^{142}$ A defence lawyer submitted an affidavit to the Supreme Court in Rogers stating that "she would not advise participation in such video interviews if the material could end up being broadcast on the decision of the police officer in charge". ${ }^{143}$ An Australian court has commented that fewer people may participate in videoed police interviews "if it became known that there was a possibility of the interview being shown to all the world on public television". ${ }^{144}$ Gathering such information to use as evidence is undoubtedly a critical part of police business, and problems with supply could pose a significant problem. Such evidence could be crucial to whether a suspect is convicted. TVNZ suggested as much in their documentary about Rogers. ${ }^{145}$

Unclear law and rules may affect the relationship between the police and the media. While it is important to protect the rights of individuals and the continued supply of information to the police, it is also important to allow the police to give information to the media when necessary. The Law

139 Rogers, above n 1, para 31 Elias CJ.

140 Law Commission, above n 97, para 458; But see Valerie P Hans and Neil Vidmar "The Verdict on Juries" (2008) 91 Judicature 226.

141 Law Commission above, n 97, para 467.

142 Rogers $v$ Television New Zealand Ltd, above n 14, para 119 William Young P.

143 Rogers, above n 1, para 30 Elias CJ.

144 South Australian Telecasters Limited v Director of Public Prosecutions [1995] 64 SASR 123, 128 (SCSA).

145 TVNZ "The confession the jury didn't see" (18 November 2007) Sunday. But see Steven Price "Sunday and the Rogers case" (19 November 2007) Media Law Journal www.medialawjournal.co.nz (accessed 9 July 2009). 
Commission has found that the law of contempt as is stands has a "chilling effect" on media coverage, ${ }^{146}$ as it is too vague. While they were concerned such vagueness would make the media over-cautious when reporting, it seems it may also make the police over-cautious when releasing information to the media. This would impact on the ability of the police to defend their actions in an investigation, and they may therefore be subject to unbalanced criticism. An example of this was a recent armed robbery resulting in death where the response of the police was criticised. ${ }^{147}$ The police were unable to supply the media with 111 tapes from their Communications Centre to give the public better understanding of the police response, as they were advised of possible contempt of court. ${ }^{148}$ The media play an important role in informing the public and if the police cannot supply a reasonable amount of information this greatly impacts on the ability of the media to fulfil this role.

If the media publish information released by the police they too may be exposed to liability in contempt of court, ${ }^{149}$ or breach of confidence as a third party if they receive "information in circumstances where that person knows or ought to have known that it had been divulged in a breach of an obligation of confidence". ${ }^{150}$ The High Court ${ }^{151}$ and Supreme Court ${ }^{152}$ in Rogers suggested that TVNZ would have known the video was subject to an obligation of confidence. However, it is likely the public interest arguments relevant to Rogers' privacy claim would apply here (although not to contempt).

\section{B The Need for Clarification and Comprehensive, Enforced Police Guidelines}

The law relating to police release of information to the media requires clarification. Some areas of the law are very uncertain, for example, contempt of court. The Law Commission has suggested that the law relating to sub judice contempt could be codified. ${ }^{153}$ Codification may help prevent the inadvertent release of information in contempt of court and overcautious withholding of information. However, codification in the United Kingdom has arguably not made contempt law much clearer. ${ }^{154}$

146 Law Commission, above n 97, para 465.

147 "Singh Complaint" (19 June 2008) The Press Christchurch 3.

148 Obtained under Official Information Act 1982, Request to the New Zealand Police 24 July 2008.

149 Solicitor-General v Wellington Newspapers Ltd, above n 93, 57 (CA) McGechan J.

$150 P v D[2000] 2$ NZLR 591, para 15 (HC) Nicholson J.

151 Rogers $v$ Television New Zealand Ltd, above n 13, para 53 Judgment for the Court.

152 Rogers, above n 1, para 16 Elias CJ.

153 Law Commission, above n 97, para 459.

154 Law Commission, above n 97, para 460. 
As the law relating to police release of information to the media is fragmented and involves legislation, regulations and common law rules, the most valuable way to clarify the law for the police would be to have clear guidelines explaining the applicable law, contained in a single document. The author requested information under the OIA relating to the internal rules, policies, circulars or memorandums containing guidance on the release of information by the police to the media. The General Instructions relating to media, Police College selection and induction course notes, a police media relations document and a homicide media strategy document were received. This seems too fragmented, and the introduction of the Code of Conduct further adds to this fragmentation. These documents provide little guidance on the law.

The General Instructions relating to police and media interaction are brief at only twelve pages long and focused on the procedural elements of decisions rather than substantive elements. For example, these instructions refer to Regulation 7 (now repealed), but provide little guidance beyond requiring decisions to be referred up the ranks of the police force. ${ }^{155}$ No guidance is given on what basis such decisions should be made. While there are three police documents specifically relating to dealing with the media, they deal more with fostering an effective media/police relationship than the applicable law. In the largest document entitled "Media Relations" eleven pages are dedicated to techniques for writing news releases, drafting radio broadcasts and giving interviews to the media while two pages are dedicated to offering an explanation of the sub judice rule, one paragraph summarises the Police Regulations, and the OIA is mentioned but not in any way explained. Breach of confidence considerations are not mentioned. ${ }^{156}$

The media guidance notes released by the Association of Chief Police Officers of England, Wales and Northern Ireland are, in contrast to New Zealand's General Instructions, fifty four pages long. ${ }^{157}$ While the implementation of these notes is left up to individual chief constables, the guidance contained in them is clearer and in far greater detail. In particular, these notes focus more on the relevant legal principles. For example, comprehensive definitions of public interest are given ${ }^{158}$ and guidance is given on when the release of information meets a policing purpose. ${ }^{159}$ While notes are still unclear in parts, they have the advantage of being contained in one document. This is not so in New Zealand. For example guidance on release of pre-trial information, listing information that may safely be given to the media, is included in the New Zealand Police media

155 Police Media Services, above n 53.

156 New Zealand Police, above n 60

157 Association of Chief Police Officers of England, Wales and Northern Ireland: Media Advisory Group Guidance Notes www.acpo.police.uk (accessed 9 August 2009).

158 Ibid, 3.

159 Ibid, 40. 
strategy document for homicide, ${ }^{160}$ but not in any other media police documents, General Instructions or Code of Conduct.

Provision for regulation of police disclosure was considered in the drafting of the Policing Act 2008. The Policing Bill 2007 contained provision under clause 100(1)(b) for regulations "regulating the disclosure by any police employee of information coming into his or her possession in the course of performing his or her duties as a police employee". ${ }^{161}$ However, the Select Committee considered that legislation such as the Protected Disclosures Act 2000 adequately addressed disclosure of information by the police. ${ }^{162}$ The author disagrees with such a view as that Act deals with "whistle-blowing" not release of information to the media. ${ }^{163}$ A Regulation 7 equivalent has not been included in any new regulations or in the Policing Act.

The Policing Act 2008 requires under section 20 that the Commissioner of the Police provide a code of conduct for police staff. The Code contains some guidance on confidentiality. However, it does not provide more guidance than regulation $7 \mathrm{did}$. The confidentiality provisions are brief and contain vague references to "recognised standards, policies and directives" and "official duties". ${ }^{164}$ In order for police employees to determine when information ought to be released they would need to refer to various other police documents. The Code does not mention the legal basis for confidentiality in police information and thus provides no additional guidance on matters such as breach of confidence or contempt of court. This seems a wasted opportunity to provide a definitive source of the rules relating to police release of information to the media, but instead adds to the fragmented nature of the rules without providing valuable guidance on the applicable law.

While it is true that the law and rules relating to release of information by the police to the media are generally fragmented and unclear, with regards to the Rogers tape the police internal rules are actually very clear as two documents expressly say video interviews and confessions ought not to be released. ${ }^{165}$ Clarifying the rules and law may go some way in ensuring compliance. However, there needs to be enforcement of police rules. It is up to each individual to enforce an obligation of confidence or privacy right. As discussed above, contempt of court is rarely enforced and even then the defendants are usually the media. The OIA does, of course, bar any civil or criminal proceeding

160 New Zealand Police, above n 61, 11.

161 Policing Bill 2007, no 195-1, cl 100(1)(b).

162 Policing Bill 2007, no 195-2 (the commentary).

163 Protected Disclosures Act 2000, s 5.

164 New Zealand Police, above n 62.

165 Criminal Investigation Branch, above n 58, 7; New Zealand Police, above n 60, 11, 17. 
"in respect of the making available of that information" released in good faith, pursuant to the Act. ${ }^{166}$ Therefore, the police need to ensure their rules are followed.

It is unclear how often the police enforce their internal rules. The author requested information about any inquiries and disciplinary actions that the police have conducted after police staff have released information to the media. As there was "no easy way of accessing this information" four examples were supplied instead. ${ }^{167}$ Of these, in two cases leaks of information to the media were suspected but were unable to be proven, in one case the staff member left before the inquiry was completed and in the other case Rogers the police declined to give information on any inquiry citing "privacy of a natural person". ${ }^{168}$ Perhaps the classification of unauthorised release of police information as serious misconduct in the police Code of Conduct indicates intention of greater enforcement by the police.

\section{CONCLUSION}

This paper has dealt with the circumstances in which the police are constrained by the law and internal police rules in giving information such as the Rogers tape to the media. Relevant to such release are the Police Regulations, internal police rules and Code of Conduct, breach of confidence, and contempt of court. The OIA impacts on the release of information and provides protection for release in some circumstances. It is unlikely that the Rogers tape was an isolated example of police release of such information. It seems that the criticism of the judges in the Rogers case was well founded. There were several possible breaches of the law and internal police rules when the police gave TVNZ the videotape and there is potential for breaches with the release of similar information. As a whole, the law and rules relating to the release of information by the police to the media are fragmented and unclear. There are also issues with compliance and enforcement. This affects individual rights, the supply of similar future information to the police and the relationship between the police and the media. The most effective way to improve clarity and compliance would be to make comprehensive and enforced guidelines available to police staff.

\footnotetext{
166 Official Information Act 1982, s 48(1).

167 Obtained under Official Information Act 1982, Request to the New Zealand Police 24 July 2008).

168 Obtained under Official Information Act 1982, Request to the New Zealand Police 24 July 2008.
} 
